\title{
The development of tourism: the experience of Russia
}

\author{
Tatiana Lavrova ${ }^{1}$, and Vladimir Plotnikov ${ }^{1, *}$ \\ ${ }^{1}$ Saint-Petersburg State University of Economics, 21 Sadovaya str., St. Petersburg, Russia, 191023
}

\begin{abstract}
Tourism - one of the promising sectors of the economy. In the world, the pace of development of tourism is outstripping. Tourism is the driver of economic growth. It acquires special significance in Russia, whose economy is actually in a state of stagnation. The authors analyze the peculiarities of tourism development in the Russian Federation taking into account the influence of external and internal factors. They assess the state of domestic and incoming tourism, as well as identify trends in the development of tourism in the country. Prospective directions of development of the tourism industry are considered. Of practical interest is the author's classification of factors that have a positive and negative impact on the development of tourism. The results of the research can be claimed in the management of tourism development not only at the national, but also at the regional and municipal levels.
\end{abstract}

\section{Introduction}

Tourism occupies an important place in the economic complex of countries, regions, and individual cities. Its value is also great in the world economic system. The development of tourism contributes to further deepening the processes of globalization, integration and international specialization of countries. Governments of many countries view tourism as a driver of economic growth. This applies to Russia too.

The market of tourist services of the Russian Federation requires the development and introduction of new types of tourism, effective mechanisms that enhance the competitiveness of the industry in modern conditions. At the same time, one should speak about competitiveness not only at the national, but also at the international level. Solving issues related to the development of tourism in Russia, adapting the industry to changing external and internal conditions, improving the mechanism of state regulation contribute to the formation of trends in the development of tourism in the country for the long term.

The aim of the article is to analyze the state of tourism in Russia and determine the prospects for its development.

\section{The importance of tourism in the modern economy}

\footnotetext{
*Corresponding author: plotnikov_2000@mail.ru
} 
At present, tourism has become one of the leading sectors of the world economy. According to the World Tourism Organization (UNWTO) [1], in 2016 revenues from international tourism amounted to about $\$ 1,220$ billion. The annual turnover of tourism in the world is about 4.7 trillion US dollars. International tourism accounts for $7 \%$ of world exports of goods and services. International tourist arrivals are growing very dynamically: they have increased from 25 million people in 1950 to 1,235 million people in 2016. By 2020 , the number of tourist arrivals will exceed, according to forecasts, 1.6 billion people, world tourism revenues in 2020 will increase to 2 trillion US dollars.

The Russian Federation has a high tourist potential. But, at present the country occupies an insignificant place in the world tourist market. Its share is about 1\%. In Russia, tourism is an important direction of economic development, which requires constant improvement of forms and methods of managing the development of the tourism industry. In all spheres of tourist activity, both at the level of state structures and business, new forms of work are being sought, an expansion of the product offering and a deepening of its specialization.

According to UNWTO, the potential of Russia allows, with the appropriate level of development of the tourist infrastructure, to receive up to 40 million foreign tourists per year. At the same time, the number of tourists coming to Russia is only 22.5 million, which does not correspond to its tourist potential [2].

\section{Indicators of tourism development in Russia}

We analyzed the indicators of incoming tourist flows from different countries to the territory of the Russian Federation. Table 1 shows the number of trips of citizens of foreign countries with the purpose of tourism to the territory of the Russian Federation.

Table 1 - Number of trips of citizens of foreign countries with the purpose of tourism to the territory of the Russian Federation in 2015-2016

\begin{tabular}{|l|c|c|c|}
\hline \multicolumn{1}{|c|}{ Country } & 2015 & 2016 & The change, $\%$ \\
\hline 1. Finland & 1415853 & 1319030 & -7 \\
\hline 2. China & 1121536 & 1288720 & 15 \\
\hline 3. Poland & 1725157 & 1017462 & -41 \\
\hline 4. Germany & 553493 & 566434 & 2 \\
\hline 5. Mongolia & 378196 & 522026 & 38 \\
\hline 6. Estonia & 357377 & 414147 & 16 \\
\hline 7. Latvia & 278265 & 288682 & 4 \\
\hline 8. United States & 233379 & 238633 & 2 \\
\hline 9. Italy & 191071 & 192140 & 1 \\
\hline 10. Israel & 162046 & 178633 & 10 \\
\hline Total for the Top-10 & 6416373 & 6025907 & -6 \\
\hline Total for all countries & 26851658 & 24551444 & -9 \\
\hline
\end{tabular}

Source: compiled by authors on Russian Federal Agency for Tourism data.

Based on the analysis of the data presented in Table 1, we have drawn the following conclusions:

- the number of trips of foreign citizens living in foreign countries that entered the Russian Federation with tourist purposes in 2016 was 24,551,444, which is 9 percent less than in 2015;

- from the first ten countries presented in Table 1, 6,025,907 trips were made to the Russian Federation for tourism purposes in 2016, which is 6 percent less than in 2015;

- the number of tourists from foreign countries in 2016 decreased by 2,300,214 people, compared with 2015. 
The number of trips of citizens of countries of near abroad with the purpose of tourism to the territory of the Russian Federation is presented in Table 2.

Table 2 - Number of trips of citizens of countries of near abroad with the purpose of tourism to the territory of the Russian Federation in 2015-2016

\begin{tabular}{|l|c|c|c|}
\hline \multicolumn{1}{|c|}{ Country } & 2015 & 2016 & The change, $\%$ \\
\hline 1. Ukraine & 8911705 & 8569264 & -4 \\
\hline 2. Kazakhstan & 4711082 & 3564152 & -24 \\
\hline 3. Azerbaijan & 856349 & 898426 & 5 \\
\hline 4. Uzbekistan & 797484 & 596520 & -25 \\
\hline 5. Armenia & 552142 & 596041 & 8 \\
\hline 6. Abkhazia & 416673 & 410566 & -1 \\
\hline 7. Tajikistan & 458021 & 410013 & -10 \\
\hline 8. Moldova & 491196 & 409194 & -17 \\
\hline 9. Kyrgyzstan & 373616 & 397842 & 6 \\
\hline 10. South Ossetia & 117707 & 111370 & -5 \\
\hline 11. Georgia & 47216 & 65336 & 38 \\
\hline 12. Turkmenistan & 12822 & 7912 & -38 \\
\hline Total for the Top-12 & 17746013 & 16036636 & -10 \\
\hline Total for all countries & 26851658 & 24551444 & -9 \\
\hline
\end{tabular}

Source: compiled by authors on Russian Federal Agency for Tourism data.

Analysis of the data in Table 2 (incoming tourism from the near abroad countries) showed that in 2016, 16,036,636 trips were made to the Russian Federation for tourist purposes, which is $1,709,377$ trips less than in 2015. The largest number of tourists in 2016 came from Ukraine $(8,569,264$ people), Kazakhstan $(3,564,152$ people) and Azerbaijan (898,426 people). In most countries there is a decrease in the tourist flow. The maximum reduction of trips with tourist purposes in the Russian Federation in 2016 was noted in Turkmenistan. In 2016, the number of trips of citizens with tourist purposes from Turkmenistan was reduced by $38 \%$ and amounted to 7,912 trips. The maximum increase in the number of trips of citizens with tourist purposes in the Russian Federation in 2016 was registered from Georgia. From Georgia, 65,336 trips to Russia were made, which is $38 \%$ more than in 2015.

In general, the number of incoming tourists to the Russian Federation has declined. This is the result of the influence of various socio-economic and political factors. Therefore, the study of the influence of these factors on the development of international tourism, on the change in the dynamics of the tourist flow is of great importance.

\section{Factors that influence the development of tourism}

The degree of development of tourism in any country, including in the Russian Federation, is determined to a large extent by the level of development of infrastructure and tourist service, the capacity of the territory to receive tourists, the ecological condition, the level of economic development, provision of labor resources, material resources and financial capabilities of the region hosting tourists.

Currently, there is a growing demand for trips to traditional Russian resort destinations. The tourist season of 2016 showed a great surge of interest in recreation at Russian resorts. In the rating of popularity among Russian tourists, rest in their country took the 5th place, behind only Spain, Turkey, Cyprus and Greece. (It should be borne in mind that these countries are places of traditional rest of Russians near the sea. The sea is an important destination for the inhabitants of the northern country.) Table 3 presents the structure of factors affecting the development of tourism [3]. 
Table 3 - Classification of the factors of development of international tourism

\begin{tabular}{|c|c|}
\hline Positive factors & Negative factors \\
\hline $\begin{array}{l}\text { - geographic location of the country favorable } \\
\text { for tourism development; } \\
\text { - the presence of marine or oceanic beaches; } \\
\text { - the presence of natural parks }\end{array}$ & $\begin{array}{l}\text { - remoteness from transport routes and } \\
\text { inaccessibility of the country's territory for } \\
\text { tourists; } \\
\text { - absence of water bodies, sea or oceanic } \\
\text { beaches }\end{array}$ \\
\hline $\begin{array}{l}\text { - comfortable climatic conditions, temperature } \\
\text { regime }\end{array}$ & $\begin{array}{l}\text { - harsh climate, a small number of sunny, warm } \\
\text { days }\end{array}$ \\
\hline - rich natural potential & $\begin{array}{l}\text { - the presence of monotonous landscapes, the } \\
\text { absence of a variety of species of flora and } \\
\text { fauna }\end{array}$ \\
\hline $\begin{array}{l}\text { - the presence of objects of cultural and } \\
\text { historical heritage; } \\
\text { - developed excursion network of routes } \\
\text { throughout the country }\end{array}$ & $\begin{array}{l}\text { - lack of objects of cultural and historical } \\
\text { heritage; } \\
\text { - poorly developed network of sightseeing } \\
\text { routes }\end{array}$ \\
\hline $\begin{array}{l}\text { - availability of accommodation facilities of } \\
\text { different levels of comfort; } \\
\text { - a wide variety of resort facilities; } \\
\text { - availability of international network hotels }\end{array}$ & $\begin{array}{l}\text { - availability of top-level hotels only in major } \\
\text { cities of the country; } \\
\text { - lack of accommodation facilities; } \\
\text { - absence or insufficient development of resort } \\
\text { facilities }\end{array}$ \\
\hline $\begin{array}{l}\text { - high level of tourist safety; } \\
\text { - political stability in the country; } \\
\text { - low level of terrorist threat }\end{array}$ & $\begin{array}{l}\text { - insufficient level of safety of tourists; } \\
\text { - political instability; } \\
\text { - high level of terrorist threat }\end{array}$ \\
\hline $\begin{array}{l}\text { - high level of well-being of the population; } \\
\text { - availability of social guarantees; } \\
\text { - high level of tourist service and medical } \\
\text { services for tourists }\end{array}$ & $\begin{array}{l}\text { - low level of welfare of the population; } \\
\text { - poor development of social guarantees; } \\
\text { - low level of service and medical care for } \\
\text { tourists }\end{array}$ \\
\hline $\begin{array}{l}\text { - high technological level of the country; } \\
\text { - development of mobile communications, the } \\
\text { Internet; } \\
\text { - comfortable living and resting conditions }\end{array}$ & $\begin{array}{l}\text { - low level of technological development; } \\
\text { - lack of comfortable living conditions; } \\
\text { - lack of a developed communication system, } \\
\text { the Internet }\end{array}$ \\
\hline $\begin{array}{l}\text { - increase of the level of solvency of the } \\
\text { population; } \\
\text { - economic stability, absence of crises }\end{array}$ & $\begin{array}{l}\text { - decrease in the level of solvency of the } \\
\text { population of countries; } \\
\text { - a low level of economic stability, an } \\
\text { increasing phase of crisis phenomena }\end{array}$ \\
\hline
\end{tabular}

The most important direction of tourism development is the differentiation of the tourism product, the development of new types and directions of tourism for both foreign tourists and residents. The analysis showed that the following areas of development of domestic tourism in Russia are the most popular at the moment:

1. Excursion tours (to Moscow, St. Petersburg, the city of the "Golden Ring" - Vladimir, Suzdal, Novgorod, Rostov the Great, etc.).

2. Organization of winter hunting and fishing - one of the developing areas of domestic tourism.

3. Adventure tourism. Organized rafting along the rivers of Altai, horse routes along the banks of the Volga, in the Altai, Bashkiria, Nizhny Novgorod region, etc.

4. Ecological tourism is actively developing in various regions of the country, where tourists make fascinating trips on specially developed routes of reserves and national parks.

In recent years, natural or ecological tourism has become increasingly popular in Russia. It has economic advantages. Unlike other types of tourism, eco-tourism in national parks requires significantly less organizational costs and capital investments in the 
development of infrastructure. Also specific are the tourists themselves. Ecological tourism is focused on the category of tourists who do not show high requirements to the level of service.

Tourism is actively developing in such regions of Russia as the Black Sea coast of the Krasnodar Territory, the region of the Caucasian Mineral Waters, the Altai Territory, Moscow and its suburbs, St. Petersburg, Leningrad Region, Karelia (Kizhi). The most actively developing ecological, sports, extreme, skiing, cognitive, business, therapeutic and health, cruise, fishing and hunting, event and gastronomic tourism. Also popular is the individual and children's and youth recreation.

The variety of landscapes allows to develop many types of tourism. Russia has resorts on the Black and Baltic Seas, which makes it suitable for beach holidays, treatment and health improvement at sea. Also, resort treatment is quite developed in places where there are springs of mineral waters. High popularity is gaining the route "Golden Ring", whose project is now an example of successful investment. On this route there are about 5000 objects of cultural heritage, one fifth of all museums in Russia.

\section{Recommendations for the development of tourism}

As an important recommendation for optimizing the development of tourism in Russia, we should note the adaptation of the system of state regulation $[4,5,6$, etc.] to the changing conditions of the external and internal environment. To ensure the effective development of the system of state regulation and support of tourist activities in Russia, we recommend the implementation of the following measures:

- improvement of legislation in matters of tourism development, simplification of visa procedures, customs and border control;

- state regulation of pricing in the sphere of tourism;

- formation of the system of compulsory insurance of people during travel with tourist purposes;

- improving the quality of service to tourists in accordance with the requirements of technical, regulatory, legal acts and standards;

- training of specialists in the field of tourism;

- development of advertising and information materials about the tourist and recreational potential of the regions of the Russian Federation, their publication in mass circulation as printed publications, their placement on the Internet and distribution in various countries of the world;

- participation in major Russian and international exhibitions of the tourism industry;

- the creation of a common database on tourism, which would contain information about tours and excursions, a numbered fund and accommodation facilities;

- attraction of investments for reconstruction and construction of tourist facilities;

- monitoring of the country's regions in the field of in-depth study of the tourist and recreational potential; Identification of territories and objects of tourist interest;

- expansion of the list and volumes of additional services;

- application of new technologies in the construction of tourist and hotel complexes and other objects of the tourism industry;

- development of passenger transportation by road and rail.

\section{Conclusion}

Summing up the analysis, we can conclude that to optimize the development of tourism in the country it is necessary to identify and in the shortest period to solve the main problems 
that hinder the process of its improvement. In Russia, it is necessary to activate the process of developing new species and tourist destinations, to adjust the regional concepts of tourism development, to ensure that the world practices and experience in the formation of tourist and recreational complexes are taken into account. This will overcome the negative trend in the development of tourism in Russia. We are sure that tourism can become a locomotive branch of the economy of the Russian Federation.

\section{References}

1. URL: http://tourlib.net/wto/WTO_highlights_2017.pdf.

2. URL: http://textarchive.ru/c-2340694.html.

3. T. A. Lavrova. Analysis of trends in the development of international tourism in modern conditions. St. Petersburg Economic Journal, 2 (2017).

4. V. Plotnikov, G. Fedotova, E. Popkova, A. Kastyurina. Harmonization of strategic planning indicators of territories' socioeconomic growth. Regional and Sectoral Economic Studies, 15 (2) (2015).

5. Y. Vertakova, Y. Polozhentseva, M. Klevtsova, E. Leontyev. Government support tools for small business: Russian and foreign experience. Proc. of the 27th Int. Business Information Management Association Conf. Innovation Management and Education Excellence Vision 2020: From Regional Development Sustainability to Global Economic Growth (2016).

6. T. A. Golovina, P. A. Merkulov, A. V. Polyanin. Strategic vectors of the development of the state support of youth entrepreneurship in Russia. Ekonomicheskaya Politika, 12 (5) (2017). 